\title{
Pemanfaatan Internet Untuk Memvariasikan Sumber Belajar Bahasa Inggris dalam Meningkatkan Kinerja Guru
}

\author{
Fitria Nur Hamidah ${ }^{1}$, Dion Yanuarmawan ${ }^{2}$ \\ fidahfnh@gmail.com ${ }^{1}$, dionyanuarmawan@gmail.com² \\ Politeknik Kediri
}

\begin{abstract}
To become a qualified and professional educator, teachers at the senior high school are required to have various skills to support teaching and learning activities. The goal of this program is to provide internet mastery skills by high school teachers to facilitate the search for English learning resources and introduce and deepen the knowledge and skills of supporting websites in learning English. The Outcomes were obtained; 1.) Participants had the knowledge and skills in utilizing the Internet as a varied source of English learning. 2.) Participants were able to identify and deepen the knowledge of supporting websites in learning English. 3.) The availability of 1 handout of internet utilization training to vary the English language resources to improve teacher performance. 4.) Participants had the knowledge in utilizing the internet to vary the English learning resources as evidenced by the comparison of the final outcome of the training with the participants' initial knowledge. the average value of the theory test has increased by $80-49=31$. While the average score of practice tests also increased by $77-48=29$. It proved that the training is held successfully to improve teachers performance in using internet as a source of learning.
\end{abstract}

Keywords: Internet, teaching source, Teacher Performance

Abstrak: Untuk menjadi pendidik yang berkualitas dan profesional, guru di sekolah menengah atas diharuskan memiliki berbagai keterampilan untuk menunjang kegiatan belajar mengajar. Tujuan dari program ini adalah untuk memberikan keterampilan penguasaan internet oleh guru sekolah menengah untuk memudahkan pencarian sumber belajar bahasa Inggris dan mengenalkan dan memperdalam pengetahuan tentang situs pendukung dalam belajar bahasa Inggris. Hasil diperoleh; 1.) Peserta memiliki pengetahuan dan keterampilan dalam memanfaatkan internet sebagai sumber belajar bahasa Inggris yang bervariasi. 2.) Peserta mampu mengidentifikasi dan memperdalam pengetahuan tentang situs pendukung dalam belajar bahasa Inggris. 3.) Tersedianya 1 handout pelatihan pemanfaatan internet untuk memvariasikan sumber daya bahasa Inggris untuk meningkatkan kinerja guru. 4.) Peserta memiliki pengetahuan dalam memanfaatkan internet untuk memvariasikan sumber belajar bahasa Inggris sebagaimana dibuktikan dengan perbandingan hasil akhir pelatihan dengan pengetahuan awal peserta. nilai rata-rata uji teori telah meningkat sebesar $80-49=31$. Sedangkan rata-rata skor tes latihan juga meningkat sebesar 77 $48=29$. Ini membuktikan bahwa pelatihan ini berhasil dilaksanakan untuk meningkatkan kinerja guru dalam menggunakan internet sebagai sumber. belajar. 
Kata kunci: Internet, sumber Ajar, Kinerja Guru

\section{ANALISIS SITUASI}

Di jaman globalisasi sekarang ini kebutuhan akan penggunaan teknologi dan informasi semakin tidak dapat dikesampingkan. Berbagai aktifitas manusia, tidak dapat terlepas dari pengaruh perkembangan teknologi yang semakin modern. Baik bagi kalangan rakyat umum maupun dalam dunia pendidikan (Permana et al., 2017). Kebutuhan akan pemenuhan ilmu pengetahuan dan teknologi semakin menjadi kebutuhan yang sangat penting. Bagi seorang pendidik, kebutuhan akan penguasaan teknologi merupakan hal yang harus dikuasai guna mendukung proses pembelajaran, agar tujuan pendidikan pada umumnya dapat tercapai yaitu mencerdaskan kehidupan bangsa.

Salah satu standar kompetensi pedagogik guru sekolah dasar berdasarkan permendiknas nomor 16 tahun 2007 tanggal 4 Mei 2007 tentang standar kualifikasi akademik dan kompetensi guru adalah memanfaatkan teknologi informasi dan komunikasi (TIK), termasuk internet di dalamnya untuk kepentingan pembelajaran. Internet merupakan sumber belajar yang dapat menyediakan berbagai aplikasi secara tidak terbatas, sehingga memungkinkan adanya interaksi antar penggunanya baik secara inrterpersonal maupun masal.

Untuk menjadi seorang pendidik yang berkualitas dan professional, guru pada tingkat Sekolah Menengah Atas dituntut untuk memiliki berbagai macam keterampilan dan keahlian untuk menunjang kegiatan belajar mengajar di sekolah. Di era globalisasi seperti saat ini, semua guru dituntut untuk dapat mengoperasikan internet. Karena salah satu kompetensi professional yang harus dimiliki oleh seorang guru adalah mampu memanfaatkan teknologi informasi dan komunikasi. Akan tetapi pada kenyataannya tidak semua guru di Indonesia menguasai penggunaan Internet, terutama pada ruang lingkup pedesaan. Akibatnya, peserta didik tersebut tertinggal dalam penguasaan Ilmu Pengetahuan dan Teknologi (IPTEK) atau media yang berbasis internet.

Hal ini tentu menjadi tantangan tersendiri bagi guru-guru sekolah menengah atas yang sudah tidak muda lagi, karena umumnya akan mengalami kesulitan dalam memahami suatu hal yang masih baru dalam dunia mereka. Namun, mengingat manfaat internet yang sangat banyak bagi dunia pendidikan, misalnya untuk mempermudah pencarian sumber bahan belajar Bahasa Inggris guna menunjang suksesnya proses pembelajaran mereka dituntut untuk dapat menguasai internet. 
Fitria Nur Hamidah ${ }^{1}$, Dion Yanuarmawan ${ }^{2}$

Permasalahan kurangnya guru-guru sekolah tingkat menengah atas dalam hal pengusaan IT lebih khusus dalam pengusaan internet dialami pula oleh sebagian besar guru SMA. Banyak guru di kota kediri khususnya di sekolah swasta dengan jumlah yang relatif banyak masih awam terhadap internet dan pengoperasiannya. Atas dasar permasalahan tersebut kami bermaksud ingin mengadakan workshop penggunaan internet dalam mempermudah pencarian sumber belajar Bahasa Inggris terhadap guru-guru Bahasa Inggris yang berada di kota kediri khusunya di SMA NEGERI 7 Kediri dengan maksud untuk meningkatkan keterampilan dan pengetahuan guru-guru Bahasa Inggris dalam hal IT khususnya penguasaan internet.

Tujuan yang hendak dicapai dari program ini adalah memberikan ketrampilan penguasaan internet oleh guru tingkat SMA guna mempermudah pencarian sumber belajar Bahasa Inggris, memperkenalkan dan memperdalam pengetahuan situs-situs yang mendukung dalam pembelajaran Bahasa Inggris.

\section{SOLUSI DAN TARGET}

Pelaksanaan Pengabdian kepada masyarakat diharapkan memberikan hasil terbaik untuk masyarakat sasaran yang dikenai program. Berdasarkan dua permasalahan yang akan diselesaikan maka target luaran yang dihasilkan adalah:

1. Permasalahan yang pertama adalah bagaimana tingkat penguasaan internet oleh guru tingkat SMA guna mempermudah pencarian sumber belajar Bahasa Inggris? Untuk mengatasinya dilakukan pelatihan Pemanfaatan Internet untuk Memvariasikan Sumber Belajar Bahasa Inggris dalam Meningkatkan Kinerja Guru sehingga luaran yang diperoleh:

a. Peserta memiliki pengetahuan dan keterampilan dalam memanfaatkan Internet sebagai sumber belajar Bahasa Inggris yang bervariasi.

b. Peserta mampu megenali dan memperdalam pengetahuan situs-situs yang mendukung dalam pembelajaran Bahasa Inggris

c. Tersedianya 1 handout pelatihan pemnfaatan internet untuk memvariasikan sumberbelajar bahasa Inggris untuk meningkatkan kinerja guru yang di dalamnya tertuang beberapa tutorial dan alamat situs-situs web yang menyediakan bahan Bahasa Inggris sebagai bantuan untuk belajar dan pedoman dalam mempelajari internet sebagai sumber ajar dan bervariasi.

2. Permasalahan yang kedua adalah sejauh mana para guru Bahasa Inggris mengenal situssitus yang mendukung dalam pembelajaran Bahasa Inggris? Luaran yang didapat adalah: 
Fitria Nur Hamidah ${ }^{1}$, Dion Yanuarmawan ${ }^{2}$

a. Peserta memiliki pengetahuan dan keterampilan dalam memanfaatkan internet untuk memvariasikan sumber belajar bahasa Inggris dibuktikan dengan perbandingan hasil akhir pelatihan dengan pengetahuan awal peserta.

b. Peserta dinyatakan kompeten dalam memanfaatkan internet untuk memvariasikan sumber belajar bahasa Inggris dibuktikan dengan sertifikat pelatihan.

Luaran yang dihasilkan dari pelaksanaan pengabdian kepada masyarakat pada guruguru bahasa Inggris di SMA Negeri 7 kota Kediri ini dapat memberikan dampak yang mendalam baik kognitif, afektif maupun psikomotor bagi guru-guru bahasa Inggris dalam memvariasikan sumber belajar Bahasa Inggris dengan memanfaatkan internet. Disamping itu juga dapat memberikan pengetahuan untuk meningkatkan kinerja guru dalam memanfaatkan internet sebagai seumber belajar bahasa Inggris yang bervariasi dalam proses belajar bahasa Inggris.

Tabel 1. Rancangan Target Luaran

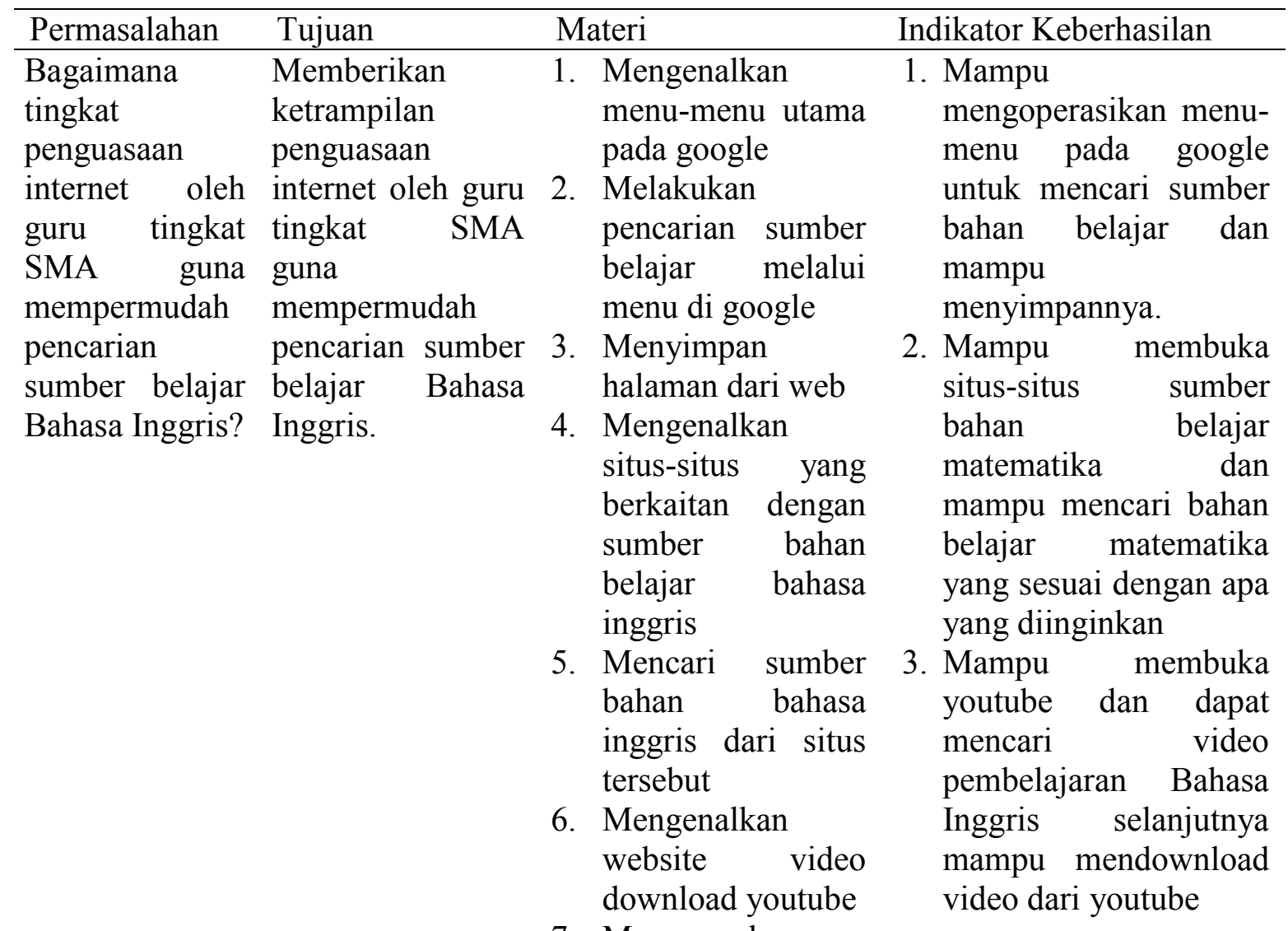

7. Menggunakan youtube untuk mencari video yang berkaitan dengan bahan belajar matematika

8. Cara 


\begin{tabular}{llll}
\hline & \multicolumn{5}{c}{ mendownload } \\
video dari youtube \\
Sejauh mana & Memperkenalkan & $\begin{array}{l}\text { Evaluasi dengan } \\
\text { menghasilkan produk }\end{array}$ & Mampu membuat variasi \\
para guru & dan & sumber bahan belajar \\
Bahasa Inggris & memperdalam & yaitu sumber belajar & Bahasa Inggris dengan \\
mengenal & pengetahuan & Bahasa Inggris yang & memanfaatkan situs-situs \\
situs-situs yang & situs-situs yang & bervariasi. & sumber belajar yang telah \\
mendukung & mendukung & & dilatihkan. \\
dalam & dalam & \\
pembelajaran & pembelajaran & & \\
Bahasa & Bahasa Inggris & & \\
Inggris? & & & \\
\hline
\end{tabular}

Pelaksanaan kegiatan dilakukan di akhir bulan september, minggu pertama dan minggu kedua bulan oktober 2017. Kegiatan dilaksanakan dalam bentuk pelatihan dan pendampingan dengan tiga kali tatap muka. Pelaksanaan kegiatan di ruang evaluasi SMA Negeri 7 Kota Kediri. Adapun metode yang akan dipakai adalah sebagai berikut dengn menggunakan Metode Pendekatan dan metode pelaksanaan. Metode pendekatan dilakukan dengan menyesuaikan paradigma para guru-guru Bahasa Inggris di SMA Negeri 7 Kota Kediri maka perlu melakukan langkah-langkah berikut ini :

a. Menghubungi kepala Sekolah dan Waka Kurikulum SMA Negeri 7 Kediri

b. Menjelaskan latar belakang dan tujuan program yang akan diterapkan

c. Memberkan motivasi kepada guru Bahasa Inggris yang ada di SMA Negeri 7 Kota Kediri agar program ini dirasakan sebagai kebutuhan untuk mereka jalankan. Caranya dengan mengumpulkan Guru-guru tersebut di ruang diskusi yang disediakan.

Sejalan dengan hal tersebut, ada beberapa metode yang telah dikembangkan untuk memposisikan para guru Bahasa Inggris yang ada di SMA Negeri 7 Kota Kediri. Hal ini perlu dilakukan agar mereka tidak hanya sebagai objek yang hanya pasif menerima pelatihan tetapi ikut berpartisipasi aktif untuk menjalankan program ini dan mengembangkannya agar tujuan dari program ini tercapai. Metode yang dilakukan adalah sebagai berikut: pertama pendekatan secara partisipatif dan dialogis, yaitu dengan cara menghubungi Kepala Sekolah dan Wakil Kepala Sekolah Bagian Kurikulum. Disini kepala sekolah dan wakil kepala sekolah bagian kurikulum menghubungi salah satu guru Bahasa Inggris untuk memberikan informasi kepada semua Guru Bahasa Inggris menganai kegiatan ini.

Setelah itu, guru-guru tersebut dikumpulkan di ruang diskusi untuk memberikan rencana jadwal workshop yang diberikan. Musyawarah disini yaitu tentang Program Pelatihan atau workshop yang akan dilaksanakan serta kendala-kendala yang dimungkinkan timbul dalam pelaksanaan program ini, sehingga dalam musyawarah ini bisa mendapatkan solusi 
Fitria Nur Hamidah ${ }^{1}$, Dion Yanuarmawan ${ }^{2}$

akan kendala tersebut. Setelah musyawarah tersebut, kami sebagai tenaga pelaksana pengabdian kepada masyarakat akan mendampingi serta memberikan pelatihan kepada khalayak sasaran dalam memberikan pelatihan tersebut.

\section{METODE PELAKSANAAN}

Pelaksanaan program pengabdian kepada masyarakat pelatihan penggunaan internet dalam pencarian sumber belajar Bahasa Inggris terdapat lima tahapan, yaitu:

a. Tahap pendahuluan

Dalam tahap ini kita mempersiapkan surat izin dengan pihak terkait, mempersiapkan tempat pelatihan, mempersiapkan alat dan bahan.

b. Tahap sosilaisasi dan audiensi

Sosialisasi mengenai pelatihan penggunaan internet ini dilakukan dengan cara mengumpulkan semua guru Bahasa Inggris di SMA Negeri 7 Kota Kediri. Lalu para peserta diberi penjelasan bahwa pembahasan pelatihan yakni mengenai apa manfaat internet, bagaimana cara pemanfaatan internet dalam mempermudah penyusunan sumber belajar Bahasa Inggris.

c. Tahap pelatihan penggunaaan internet dalam sumber belajar Bahasa Inggris berupa kegiatan pelatihan penggunan internet kepada guru-guru Bahasa Inggirs, disini pertama kalinya kita menyiapkan bahan-bahan yang dibutuhkan, kemudian beberapa dari kami mempraktekkan langsung dan memberikan pelatihan yang diikuti oleh para guru Bahasa Inggirs secara langsung setahap demi setahap. Adapun materi yang diberikan disesuaikan dengan tingkat kesiapan guru dalam penerimaan materi. Demonstrasi pelatihan internet bagi guru diawali dengan pengenalan program internet itu sendiri kemudian dilanjutkan pada pencarian dan pengolahan bahan ajar yang disediakan oleh internet. Monitoring dan pendampingan perkembangan pelaksanaan program dari mampu mengenal program internet sampai guru dinilai sanggup dalam pencarian dan pemrosesan bahan ajar dari internet. Adapun meteri yang akan diajarkan dalam kegiatan ini adalah:

1. Mempelajari menu utama pada google

Fokus pembahasan adalah penggunaan google sebagai mesin pencari. Menu yang ada di google antara lain: webs, images, books, translates, scholar, blogs. Gmail dan documents. Untuk melakukan pencarian dengan karakteristik yang lebih spesifik dapat kita lakukan dengan menggunakan google advanced search. Mesin pencari tersebut dapat dimanfaatkan untuk mencari bahan ajar atau pembelajaran Bahasa Inggris SMA. 
2. Mengenal situs-situs sumber belajar Bahasa Inggris

Fokus pembahasannya adalah mengenalkan situs sumber belajar Bahasa Inggris yang cukup bermanfaat dan yang menyediakan berbagai produk pembelajaran. Website yang dimaksud seperti Buku Sekolah Elektronik (http://bse.depdiknas.go.id) yang menyediakan berbagai buku elektronik dari semua mata pelajaran untuk semua jenjang sekolah. Selain itu juga ada Website-website lain yang diberikan kepada guru-guru Bahasa Inggris.

3. Mengenal perangkat bantu akses online

Fokus pelatihan adalah mengenalkan dan mempelajari perangkat bantu akses online antara lain adalah kamus online, penerjemah online dengan Google Translate, Youtube Video Downloader, penampil dokumen online dan tes online. Seiring dengan era teknologi informasi saat ini, sudah saatnya para guru Bahasa Inggris SMA memanfaatkan website tersebut sesuai kebutuhan siswa untuk meningkatkan kualitas proses pembelajaran di kelas.

4. Melakukan pencarian Video terkait sumber belajar Bahasa Inggris

Fokus pelatihan adalah memberikan pengarahan dan pengetahuan mengenai website yang memfasilitasi pencarian video sehingga kita dapat memilih kualitas gambar yang lebih jernih. Pada pembahasan ini akan dibahas adalah pencarian video dengan menggunakan YouTube (http://youtube.com)

d. Tahap Evaluasi Akhir

Evaluasi kegiatan berupa mengevaluasi perkembangan penerapan program internet dan pencarian sumber belajar yang dilakukan melalui web browser yang diterapkan dalam proses pembelajaran. Pengukuran keefektifan tersebut ditandai dengan guruguru Bahasa Inggris tingkat SMA khususnya di SMA Negeri 7 kota Kediri mampu mengaplikasikan internet dalam proses pembelajaran.

\section{HASIL DAN LUARAN}

\section{Tingkat penguasaan internet oleh guru-guru Bahasa Inggris SMA Negeri 7 guna} dalam pencarian sumber belajar Bahasa Inggris

Kondisi awal adalah kondisi peserta pelatihan, ketika pemateri belum memberikan tindakan apapun untuk meningkatkan kompetensi peserta pelatihan. Tes teori kondisi awal untuk mengetahui tingkat kompetensi peserta pelatihan sebelum pelatihan dilaksanakan, dilakukan tes kondisi awal teori tentang internet sebagai sumber belajar, dengan 
Fitria Nur Hamidah ${ }^{1}$, Dion Yanuarmawan ${ }^{2}$

menggunakan soal tes essay atau uraian. Hasil dari tes teori pada kondisi awal yang menunjukkan pengetahuan teori peserta sebelum mengikuti proses tatap muka pembelajaran mengenai teori pelatihan ditunjukkan pada tabel 3. Soal-soal tes teori kondisi awal yang diberikan dalam bentuk uraian. Dengan tes kondisi selain untuk mengetahui tingkat pemahaman teori peserta sebelum mengikuti pelatihan juga dapat dipakai sebagai strategi untuk menerapkan metode pelatihan yang tepat, sehingga proses pelaksanaan pelatihan dapat berlangsung dengan baik dan dapat menghasilkan kompetensi yang diharapkan. Sistem pemberian nilai yang dipergunakan pada materi ini adalah sebagai berikut :

Tabel 2. Kualifikasi Nilai

\begin{tabular}{ll}
\hline Nilai & Kualifikasi \\
\hline $0-25$ & Rendah sekali \\
$26-51$ & Rendah \\
$52-68$ & Sedang \\
$69-84$ & Baik \\
$85-100$ & Baik sekali \\
\hline
\end{tabular}

Dari pelaksanaan tes teori pada kondisi awal, didapatkan hasil sebagai berikut:

Tabel 3. Deskripsi Nilai Tes Teori Kondisi Awal

\begin{tabular}{ll}
\hline Unsur Nilai & Nilai \\
\hline Nilai maksimum & 65 \\
Nilai minimum & 35 \\
Rentang Nilai & 30 \\
Nilai rata-rata & 49
\end{tabular}

Selanjutnya dari tabel 4 , distribusi frekwensi nilai tes teori kondisi awal sebagai berikut :

Tabel 4. Distribusi Frekuensi Nilai Tes Teori Kondisi Awal

\begin{tabular}{llll}
\hline Nilai & Kategori & Frekwensi & $(\%)$ \\
\hline $0-25$ & Rendah sekali & 0 & 0 \\
$26-51$ & Rendah & 4 & 57 \\
$52-68$ & Sedang & 3 & 43 \\
$69-84$ & Baik & 0 & 0 \\
$85-100$ & Baik sekali & 0 & 0
\end{tabular}

Dari tabel nilai tes teori tersebut diatas dapat disimpulkan bahwa secara umum pada saat sebelum mengikuti proses pembelajaran pelatihan, semua peserta memiliki kompetensi teori yang rendah, belum memenuhi indikator keberhasilan yang diharapkan, oleh karena 57\% peserta pelatihan memiliki nilai teori dalam kategori 'rendah' dan $43 \%$ peserta yang lain memiliki nilai teori dalam kategori 'sedang'.

Tes praktik kondisi awal: selain tes kondisi awal tulis selanjutnya dilakukan tes praktik. Pemateri menyiapkan materi tentang pengenalan internet sebagai sumber ajar Bahasa 
Fitria Nur Hamidah ${ }^{1}$, Dion Yanuarmawan ${ }^{2}$

Inggris dan lembar soal. Dengan menggunakan materi-materi yang telah disiapkan tersebut, pemateri memberikan tugas kepada para peserta, yaitu: pencarian sumber belajar dengan menggunakan internet.

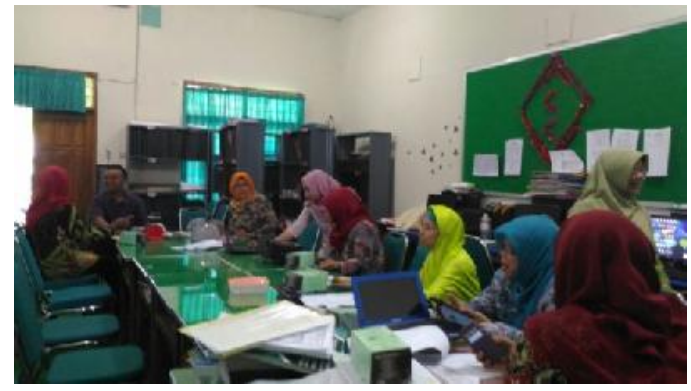

Gambar 1. Praktik Awal

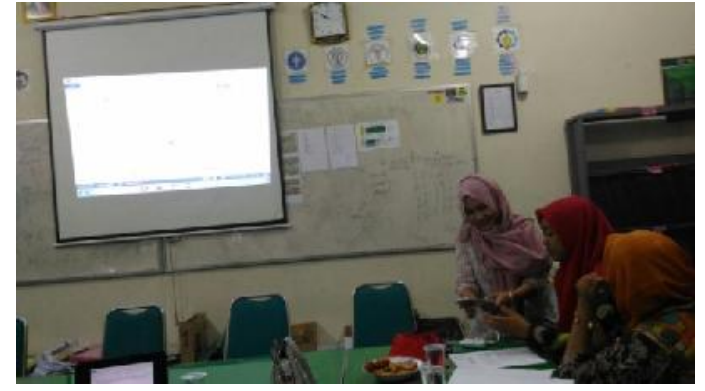

Gambar 2. Pencarian Sumber Belajar

Hasil tes praktik kondisi awal menunjukkan bahwa kompetensi peserta pelatihan dalam menggunakan internet untuk memvariasikan sumber belajar bahasa Inggris terlihat seperti pada tabel 5 berikut ini.

Tabel 5. Deskripsi Nilai Tes Praktik Kondisi Awal

\begin{tabular}{ll}
\hline Unsur Nilai & Nilai \\
\hline Nilai maksimum & 68 \\
Nilai minimum & 30 \\
Rentang Nilai & 38 \\
Nilai rata-rata & 48 \\
\hline
\end{tabular}

Selanjutnya distribusi perolehan nilai dapat ditabelkan berikut ini:

Tabel 6. Distribusi Frekuensi Nilai Tes Praktik Kondisi Awal

\begin{tabular}{llll}
\hline Nilai & Kategori & Frekwensi & $(\%)$ \\
\hline $0-25$ & Rendah sekali & 0 & 0 \\
$26-51$ & Rendah & 5 & 71 \\
$52-68$ & Sedang & 2 & 29 \\
$69-84$ & Baik & 0 & 0 \\
$85-100$ & Baik sekali & 0 & 0
\end{tabular}

Dari hasil tes praktik kondisi awal seperti tertera pada tabel 5 dan 6 di atas dapat disimpulkan bahwa kompetensi praktik pencarian sumber belajar Bahasa Inggris dengan menggunakan internet para peserta pelatihan sebelum mendapat proses pembelajaran pelatihan praktik atau kondisi awal adalah 5 peserta atau $71 \%$ mendapat nilai dalam kategori 'rendah' dan 2 peserta atau 29\% mendapat nilai dalam kategori 'sedang'.

Hasil pelatihan: hasil akhir pelatihan dapat dilihat pada tabel berikut ini:

Tabel 7. Deskripsi Nilai Tes Akhir Teori

\begin{tabular}{ll}
\hline Unsur Nilai & Nilai \\
\hline Nilai maksimum & 87 \\
Nilai minimum & 70 \\
\hline
\end{tabular}


Fitria Nur Hamidah ${ }^{1}$, Dion Yanuarmawan ${ }^{2}$

\begin{tabular}{ll}
\hline Rentang Nilai & 17 \\
Nilai rata-rata & 80 \\
\hline
\end{tabular}

Tabel 8. Distribusi Frekuensi Nilai Tes Akhir Teori

\begin{tabular}{llll}
\hline Nilai & Kategori & Frekwensi & $(\%)$ \\
\hline $0-25$ & Rendah sekali & 0 & 0 \\
$26-51$ & Rendah & 0 & 0 \\
$50-68$ & Sedang & 0 & 0 \\
$69-84$ & Baik & 4 & 57 \\
$85-100$ & Baik sekali & 3 & 43 \\
\hline
\end{tabular}

Hasil tes teori yang diperlihatkan dalam tabel 9 diatas menunjukkan bahwa sebagian besar peserta (57\%) mendapat nilai dengan kategori 'baik' dan sebagian kecil peserta (43\%) mendapat nilai dengan kategori 'baik sekali'. Jika dibandingkan dengan nilai yang diperoleh peserta pada tes teori kondisi awal, terjadi kenaikan nilai yang cukup signifikan. Dapat disimpulkan bahwa proses pembelajaran pelatihan teori pengenalan pemanfaatan internet untuk memvariasikan seumber belajar bahasa Inggris sangat berpengaruh positif terhadap hasil akhir pelatihan teori. Sedangkan hasil tes akhir praktik adalah:

Tabel 9. Deskripsi Nilai Tes Akhir Praktik

\begin{tabular}{ll}
\hline Unsur Nilai & Nilai \\
\hline Nilai maksimum & 86 \\
Nilai minimum & 65 \\
Rentang Nilai & 21 \\
Nilai rata-rata & 77 \\
\hline
\end{tabular}

Tabel 10. Distribusi Frekuensi Nilai Tes Akhir Teori

\begin{tabular}{llll}
\hline Nilai & Kategori & Frekwensi & $(\%)$ \\
\hline $0-25$ & Rendah sekali & 0 & 0 \\
$26-51$ & Rendah & 0 & 0 \\
$52-68$ & Sedang & 0 & 0 \\
$69-84$ & Baik & 4 & 57 \\
$85-100$ & Baik sekali & 3 & 43 \\
\hline
\end{tabular}

Hasil tes akhir praktik yang disajikan pada tabel 9 dan 10 menunjukkan bahwa yang mendapat nilai dengan kategori 'baik' ada 4 peserta atau $57 \%$ dan 3 peserta atau $43 \%$ mendapat nilai dengan kategori 'baik sekali'. Jika dibandingkan dengan hasil tes praktik pada kondisi awal, terjadi kenaikan kompetensi praktik yang cukup signifikan.

2. Sejauh mana para guru Bahasa Inggris mengenal situs-situs yang mendukung dalam pembelajaran Bahasa Inggris

Secara umum peserta pelatihan yang juga sebagai guru bahasa Inggris pada awal mengikuti pelatihan memiliki kompetensi yang rendah dalam memanfaatkan internet sebagai 
Fitria Nur Hamidah ${ }^{1}$, Dion Yanuarmawan ${ }^{2}$

sumber bahan ajar Bahasa Inggris. Dengan strategi dan metode dalam proses pembelajaran pelatihan teori yang baik, yaitu proses pembelajaran teori yang didukung adanya lembar kerja peserta pelatihan, dan penggunaaninternet wifi, maka kompetensi teori pemanfaatan internet untuk memvariasikan sumber bahan ajar bahasa Inggris secara signifikan dapat dikuasai dengan baik. Proses pembelajaran pelatihan praktik yang diatur dalam kelompok kecil berjalan sangat efektif, dimana setiap kelompok terdiri atas 3 sampai 4 orang dan menggunakan laptop pada saat pelatihan, sehingga setiap peserta pelatihan dapat secara efektif latihan pemanfaatan internet dalam memvariasikan sumber belajar Bahasa Inggris.
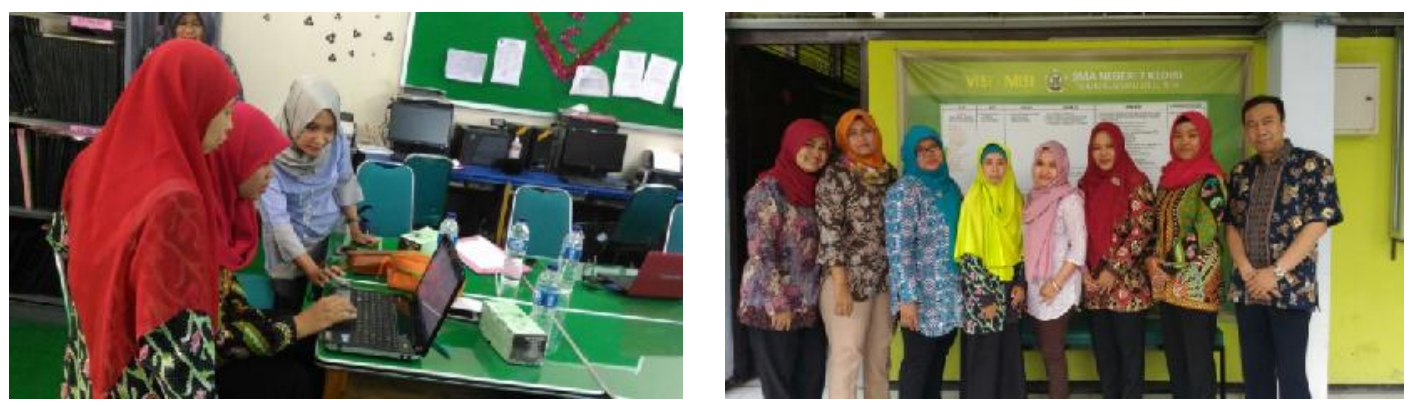

Gambar 3. Pendampingan Pencarian Sumber Belajar

Untuk mengetahui efektivitas pelatihan pemanfaatan internet untuk mevariasikan sumber belajar bahasa Inggris dalam meningkatkan kinerja guru sekaligus menjawab tujuan pelatihan yang kedua, maka hasil tes kondisi awal dibandingkan dengan hasil tes akhir. Berikut ini dipaparkan perbandingan nilai peserta pelatihan pada tabel 11.

Tabel 11. Perbandingan Nilai Teori dan Praktek Hasil Tes Kondisi Awal dan Nilai Hasil Tes Akhir

\begin{tabular}{|c|c|c|c|c|c|c|}
\hline $\begin{array}{l}\text { Unsur } \\
\text { Nilai }\end{array}$ & $\begin{array}{l}\text { Nilai } \\
\text { Tes } \\
\text { Teori } \\
\text { Awal }\end{array}$ & $\begin{array}{l}\text { Nilai } \\
\text { Tes } \\
\text { Teori } \\
\text { Akhir }\end{array}$ & Peningkatan & $\begin{array}{l}\text { Nilai } \\
\text { Tes } \\
\text { Praktek } \\
\text { Awal }\end{array}$ & $\begin{array}{l}\text { Nilai } \\
\text { Tes } \\
\text { Praktek } \\
\text { Akhir }\end{array}$ & $\begin{array}{l}\text { Peningkata } \\
\mathrm{n}\end{array}$ \\
\hline $\begin{array}{l}\text { Nilai } \\
\text { maksimum }\end{array}$ & 65 & 87 & 22 & 68 & 86 & 18 \\
\hline $\begin{array}{l}\text { Nilai } \\
\text { minimum }\end{array}$ & 35 & 70 & 35 & 30 & 65 & 35 \\
\hline $\begin{array}{l}\text { Rentang } \\
\text { Nilai }\end{array}$ & 30 & 17 & -13 & 38 & 21 & -17 \\
\hline $\begin{array}{l}\text { Nilai rata- } \\
\text { rata }\end{array}$ & 49 & 80 & 31 & 48 & 77 & 29 \\
\hline
\end{tabular}

Berdasarkan tabel 11 di atas: (1) terjadi peningkatan nilai tes teori pada unsur nilai maksimum sebesar $87-65=22$. (2) terjadi peningkatan nilai tes praktek pada unsur nilai maksimum sebesar $86-68=18$. (3) terjadi peningkatan nilai tes teori pada unsur nilai 
minimum sebesar $70-35=35$. (4) terjadi peningkatan nilai tes praktek pada unsur nilai minimum sebesar $65-30=35$. Sedangkan rentang nilai untuk tes teori dan praktek mengalami penurunan dikarenakan jarak antara nilai maksimum dan minimum semakin sedikit. Untuk nilai rata-rata tes teori mengalami peningkatan sebesar $80-49=31$. Sedangkan nilai rata-rata tes praktek juga mengalami peningkatan sebesar $77-48=29$. Secara empirik membuktikan bahwa pelatihan yang diselenggarakan berhasil untuk meningkatkan kinerja guru dalam memvariasikan internet sebagai sumber belajar bahasa Inggris melalui penggunaan dan pemanfaatan internet.

\section{SIMPULAN}

Permasalahan yang pertama adalah bagaimana tingkat penguasaan internet oleh guru tingkat SMA guna mempermudah pencarian sumber belajar Bahasa Inggris? Untuk mengatasinya dilakukan pelatihan Pemanfaatan Internet untuk Memvariasikan Sumber Belajar Bahasa Inggris dalam Meningkatkan Kinerja Guru sehingga luaran yang diperoleh:

a. Peserta memiliki pengetahuan dan keterampilan dalam memanfaatkan Internet sebagai sumber belajar Bahasa Inggris yang bervariasi.

b. Peserta mampu mengenali dan memperdalam pengetahuan situs-situs yang mendukung dalam pembelajaran Bahasa Inggris

c. Tersedianya 1 handout pelatihan pemanfaatan internet untuk memvariasikan sumber belajar bahasa Inggris untuk meningkatkan kinerja guru yang di dalamnya tertuang beberapa tutorial dan alamat situs-situs web yang menyediakan bahan Bahasa Inggris sebagai bantuan untuk belajar dan pedoman dalam mempelajari internet sebagai sumber ajar dan bervariasi.

Permasalahan yang kedua adalah sejauh mana para guru Bahasa Inggris mengenal situssitus yang mendukung dalam pembelajaran Bahasa Inggris? Luaran yang didapat adalah:

a. Peserta memiliki pengetahuan dan keterampilan dalam memanfaatkan internet untuk memvariasikan sumber belajar bahasa Inggris dibuktikan dengan perbandingan hasil akhir pelatihan dengan pengetahuan awal peserta. nilai rata-rata tes teori mengalami peningkatan sebesar $80-49=31$. Sedangkan nilai rata-rata tes praktek juga mengalami peningkatan sebesar $77-48=29$. Secara empirik membuktikan bahwa pelatihan yang diselenggarakan berhasil untuk meningkatkan kinerja guru dalam memvariasikan internet sebagai sumber belajar bahasa Inggris melalui penggunaan dan pemanfaatan internet. 
Fitria Nur Hamidah ${ }^{1}$, Dion Yanuarmawan ${ }^{2}$

b. Peserta dinyatakan kompeten dalam memanfaatkan internet untuk memvariasikan sumber belajar bahasa Inggris dibuktikan dengan sertifikat pelatihan.

\section{DAFTAR RUJUKAN}

Henry \& Perceval, Elington, Fred. 1984. A Handbook of Educational technology. London:

Kogan Page Ltd. Pentoville Road.

Nurhadiyanto. 2015. Pengaruh Manajemen Sumber Belajar Terhadap Prestasi Belajar Dengan

Kemampuan Berpikir Kritis Dan Kemampuan Bahasa Inggris Sebagai Variabel

Moderasi Di AMIK Cipta Darma Surakarta. Among Makarti Vol.8 No.15, Juli 2015.

Redhana, I Wayan. 2003. Meningkatkan Keterampilan Berpikir Kritis Siswa Melalui

Pembelajaran Kooperatif Dengan Strategi Pemecahan Masalah. Jurnal Pendidikandan Pengajaran XXXVI. II: 11-21.

Permana, E. P., Mujiwati, E. S., Sahari, S., Santi, N. N., Damariswara, R., Mukmin, B. A., ...

Saidah, K. (2017). Pelatihan Penulisan Karya Ilmiah Untuk Guru Sekolah Dasar Pada

Anggota Gugus 1 Kecamatan Ringinrejo Kabupaten Kediri. Ppm, 1(1), 52-68. Retrieved from http://ojs.unpkediri.ac.id/index.php/

Rumpagaporn, Methinee Wongwanich and I Gusti Ngurah Darmawan. 2007. Students' Critical Thinking Sskills in a Thai ICT Schools Pilot Project. International EducationJournal, 2007, 8(2), 125-132. ISSN 1443-1475 (C) 2007 Shannon Research Press.http://iej.com.au 125.

Sukarta , I Nyoman, S.Pd., M.Si, dkk. 2012. Pelatihan Pembelajaran Inovatif Bagi Guru-Guru

Di Smp Negeri 2 Kubu. Jurnal Pengabdian Kepada Masyarakat. Vol.1 Juli 2012. ISSN: 1410-4369.

Suyanto, Asep \&Herman. 2007. Web Design Theory and Practices, Yogyakarta: Andi offset. 